\title{
Murine Astrocytes Express a Functional Chemokine Receptor
}

\author{
Shigeyuki Tanabe, Michael Heesen, Michael A. Berman, Michael B. Fischer, Izumi Yoshizawa, Yi Luo, and \\ Martin E. Dorf
}

Department of Pathology, Harvard Medical School, Boston, Massachusetts 02115

\begin{abstract}
Elevated levels of chemokines have been observed in various diseases of the CNS. Little is known, however, about how these chemokines affect parenchymal cells of the CNS. The current studies examine astrocyte chemotaxis to the mouse chemokine macrophage inflammatory protein-1 $\alpha$ (MIP-1 $\alpha$ ). Murine astrocytes demonstrate directed migration along a chemical gradient in response to $10^{-10}-10^{-8} \mathrm{M}$ MIP- $1 \alpha$. Peak chemotactic responses are noted at $10^{-9} \mathrm{M}$. MIP- $1 \alpha$-induced astrocyte migration is specifically inhibitable with pertussis toxin, suggesting a role for $\mathrm{G} \alpha$ i proteins in the signaling process.
\end{abstract}

RT-PCR and in situ hybridization were used to identify expression of the murine CCR $1 \mathrm{MIP}-1 \alpha$ receptor on astrocytes. Astrocytes contain mRNA for CCR1, but messages for CCR4 and the orphan chemokine receptor MIP- $1 \alpha \mathrm{R}$-like\#1 were not detected. The combined results suggest that a functional chemokine receptor is expressed on resident cells of the CNS. We speculate that the interactions of chemokines with astrocytes are involved in inflammatory reactions of the CNS.

Key words: astrocytes; chemokines; chemokine receptors; chemotaxis; inflammation; macrophage inflammatory protein$1 \alpha$; neuroimmunology
Chemokines are a family of chemoattractant cytokines that have been implicated in the pathogenesis of infectious and inflammatory diseases. Chemokine molecules are 8-10 kDa heparin-binding proteins; they have been classified into three subfamilies $(\alpha, \beta$, and $\gamma$ chemokines), defined by the spacing of cysteines in a highly conserved motif (Baggiolini et al., 1994). The $\beta$-chemokine, macrophage inflammatory protein-1 $\alpha$ (MIP-1 $\alpha)$ induces the directed migration of monocytes, T lymphocytes, and eosinophils (Taub et al., 1993; Baggiolini et al., 1994). In addition, MIP-1 $\alpha$ can activate neutrophils, basophils, and mast cells (Wolpe et al., 1988; Alam et al., 1992; Rot et al., 1992; McColl et al., 1993). Gene targeting of MIP-1 $\alpha$ resulted in reduced responses to influenza and coxackie viral infections, demonstrating the role of this chemokine in viral inflammation (Cook et al., 1995).

Chemokines are generally produced by hematopoetic cells after activation with proinflammatory agents (Baggiolini et al., 1994). Nonhematopoetic cells, however, including parenchymal cells of the CNS, also express various chemokines, especially during disease states, e.g., MIP-1 $\alpha$ levels are elevated in focal cerebral ischemia, human immunodeficiency virus type-1 (HIV-1) infection, and experimental autoimmune encephalomyelitis (EAE) (Glabinski et al., 1995; Kim et al., 1995; Schmidtmayerova et al., 1996).

EAE is an animal model of multiple sclerosis. MIP- $1 \alpha$ has been shown to play a critical role in the pathogenesis of EAE. Injection of anti-MIP- $1 \alpha$ antibody prevents recruitment of inflammatory cells into the CNS and progression of EAE development (Karpus et al., 1995). Moreover, myelin-specific T cells that induce EAE can express MIP-1 $\alpha$ (Kuchroo et al., 1993). Al-

Received April 15, 1997; revised June 9, 1997; accepted June 11, 1997.

This work was partially supported by National Institutes of Health Grants NS 31152 and CA67416 and a gift from the Multiple Sclerosis Foundation. M.H. is the recipient of a fellowship from the Deutsche Forschungsgemeinschaft.

S.T. and M.H. contributed equally to this work.

Correspondence should be addressed to Dr. Martin E. Dorf, Department of Pathology, Harvard Medical School, 200 Longwood Avenue, Boston, MA 02115 5701.

Copyright (C) 1997 Society for Neuroscience $\quad 0270-6474 / 97 / 176522-07 \$ 05.00 / 0$ though MIP-1 $\alpha$ seems to play a critical role in EAE and other diseases of the CNS (Glabinski et al., 1995; Godiska et al., 1995; Kim et al., 1995), the nonhematopoetic targets of this chemokine are not yet completely understood. In this report we examine the ability of mouse astrocytes to migrate in response to MIP-1 $\alpha$.

Chemokines act through specific receptors on the cell membrane. These chemokine receptors belong to the family of G-protein-coupled, seven transmembrane-spanning receptors. CCR1 and related chemokine receptors bind MIP-1 $\alpha$ (Gao and Murphy, 1995; Post et al., 1995; Hoogewerf et al., 1996; Meyer et al., 1996). This report also examines astrocytes for expression of MIP-1 $\alpha$ receptors.

\section{MATERIALS AND METHODS}

Mice. BALB/cHa mice of either sex were purchased from Harlan Bioproducts for Science (Indianapolis, IN) and bred in our animal facilities. Mice were maintained in accordance with the guidelines of the Committee on Animals of the Harvard Medical School and the Society for Neuroscience, and those prepared by the Committee on Care and Use of Laboratory Animals of the Institute of Laboratory Resources, National Research Council (Department of Health and Human Services, National Institutes of Health Publication 85-23, revised 1985, Bethesda, MD).

Reagents. The mouse chemokines MIP- $1 \alpha$ and MIP- $1 \beta$ were purchased from $\mathrm{R} \& \mathrm{D}$ Systems (Minneapolis, MN). Human recombinant PDGF-BB was purchased from Life Technologies (Gaithersburg, MD). These reagents were treated with Detoxi-Gel (Pierce, Rockford, IL) to eliminate endotoxin before use in chemotaxis assays.

Astrocyte isolation. Astrocytes were prepared from neonatal $(<24 \mathrm{hr})$ mouse brains, as described earlier (Hayashi et al., 1993). Briefly, after removal of the meninges, the brains were separated into single-cell suspensions by passage through nylon mesh $(112 \mu \mathrm{m}$; Tetko, Briarcliff Manor, NY). The primary glial cell cultures were maintained in MEM (Sigma, St. Louis, MO) supplemented with 10\% FCS (Sigma), $2 \mathrm{~mm}$ glutamine, $2 \mathrm{mg} / \mathrm{ml}$ glucose, $5 \mu \mathrm{g} / \mathrm{ml}$ bovine pancreas insulin (Sigma), 2.2 $\mathrm{mg} / \mathrm{ml} \mathrm{NaHCO}{ }_{3}, 50 \mathrm{U} / \mathrm{ml}$ penicillin, and $50 \mu \mathrm{g} / \mathrm{ml}$ streptomycin (referred to as complete medium) in $10 \% \mathrm{CO}_{2}$ at $37^{\circ} \mathrm{C}$. After $10 \mathrm{~d}$, the flasks were agitated on an orbital shaker (Lab-Line Orbit-Shaker, Lab Line Instruments) for $2 \mathrm{hr}$ at $250 \mathrm{rpm}$ at $37^{\circ} \mathrm{C}$, and the nonadherent oligodendrocyte and microglial cells were removed. After $13 \mathrm{~d}$, the astrocytes were trypsinized and expanded at a 1:6 ratio in complete medium. One day after expansion, the flasks were agitated as described above, and the 


\begin{tabular}{|c|c|c|c|}
\hline Gene specificity & $\begin{array}{l}\text { Primer } \\
\text { orientation }\end{array}$ & Primers & $\begin{array}{l}\text { Predicted size (bp) } \\
\text { of PCR product }\end{array}$ \\
\hline \multirow[t]{2}{*}{ CCR1 } & Sense & AGCCTACCCCACAACTACAGAA & 546 \\
\hline & Antisense & CTTGTAGGGGAAATGAGGGCTA & \\
\hline \multirow[t]{2}{*}{ CCR4 } & Sense & ATCACTTTCAGAAGAGCAAG & 1180 \\
\hline & Antisense & GTTACCCCCACTCACACCTTAC & \\
\hline \multirow[t]{2}{*}{ CCR4 } & Sense & ATCACTTTCAGAAGAGCAAG & 1164 \\
\hline & Antisense & CСTTACAAAGCGTCACGGAAG & \\
\hline \multirow[t]{2}{*}{ CCR4 } & Sense & CCAAAGATGAATGCCACAGAG & 1106 \\
\hline & Antisense & GTTACССССАСТCACACСТTAC & \\
\hline \multirow[t]{2}{*}{ CCR4 } & Sense & CCAAAGATGAATGCCACAGAG & 1090 \\
\hline & Antisense & CCTTACAAAGCGTCACGGAAG & \\
\hline MIP-1 $\alpha$ R-like\# 1 & Sense & TTTGGAATCACAGTGCCGACTC & 411 \\
\hline (Orphan receptor) & Antisense & GAGACAAGGAATAGAAACCAAGG & \\
\hline \multirow[t]{2}{*}{$\beta$-glucuronidase } & Sense & ATCCGAGGGAAAGGCTTCGAC & 301 (RNA) \\
\hline & Antisense & GAGCAGAGGAAGGCTCATTGG & 391 (genomic DNA) \\
\hline
\end{tabular}

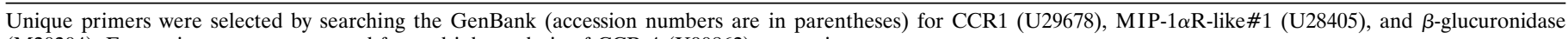
(M20204). Four primers were generated for multiple analysis of CCR-4 (X90862) expression.

medium was changed. The purity of astrocytes was $>95 \%$, as determined by indirect immunofluorescence assay with anti-Mac-1 to detect microglial cells, anti-galactocerebroside to detect oligodendrocyte contamination, and anti-glial fibrillary acidic protein (GFAP) antibodies to identify astrocytes (Smith et al., 1983).

Astrocytes used for chemotaxis assays and preparation of RNA were cultured for 20-26 d. To remove any residual oligodendrocytes and microglial cells, the flasks were agitated for $1 \mathrm{hr}$, as described above, before harvest. Thereafter the cells were trypsinized for $10 \mathrm{~min}$ at $37^{\circ} \mathrm{C}$ and washed three times. The cells were allowed to recover from trypsinization by incubation in complete medium for $90 \mathrm{~min}$ at $37^{\circ} \mathrm{C}$.

Pertussis toxin (PTx) treatment. After incubation of the cells in complete medium, the cells were washed three times and resuspended in serum-free complete medium. The cells were treated with $1 \mathrm{ng} / \mathrm{ml} \mathrm{PTx}$ (Sigma) for $60 \mathrm{~min}$ at $37^{\circ} \mathrm{C}$. After treatment, astrocytes were washed twice and suspended in endotoxin-depleted MEM containing 1\% BSA and $2.2 \mathrm{mg} / \mathrm{ml} \mathrm{NaHCO}_{3}$ (referred to as chemotaxis medium). The viability of the cells with or without PTx was $>95 \%$.

Chemotaxis assay. Cell migration was evaluated in 48-well Boyden microchambers (Neuroprobe, Cabin John, MD) as described earlier (Luo and Dorf, 1996). Mouse peritoneal macrophages, prepared as detailed elsewhere (Devi et al., 1995), were used as controls for chemotaxis assays. Astrocytes or macrophages were washed and resuspended in the chemotaxis medium $\left(4 \times 10^{6}\right.$ cells $\left./ \mathrm{ml}\right)$. Fifty microliters of cells were added to the upper well of the Boyden chamber. Thirty microliters, containing the indicated concentration of endotoxin-depleted chemokine, were placed in the lower microchamber; the wells were separated by a $14 \mu \mathrm{m}$ (astrocyte) or $5 \mu \mathrm{m}$ (macrophage) pore size polycarbonate filter (Poretics, Livermore, CA). All responses were assayed in triplicate. The chambers were incubated for $90 \mathrm{~min}$ (macrophage) or 3-4 hr (astrocyte) at $37^{\circ} \mathrm{C}$ in a moist $5 \% \quad \mathrm{CO}_{2}$ atmosphere. After incubation, the upper surface of the filters was scraped to remove nonmigrating cells. Filters were subsequently fixed in methanol and stained with Diff-Quik (Baxter, McGaw Park, IL). The number of migrating cells per high-powered field were counted at $400 \times$ magnification. At least five high-powered fields were examined in each well.

Statistics. Data are given as the mean $\pm \mathrm{SD}$. Statistical analysis was performed with Student's $t$ test; $p$ values $<0.05$ were considered significant.

Screening of astrocyte cDNA for expression of MIP-1 $\alpha$ receptor genes. Total RNA and cDNA were prepared from $8 \times 10^{7}$ astrocytes, caseinelicited peritoneal exudate (PE) cells, or L929 mouse fibroblasts using methods described elsewhere (Post et al., 1995; Heesen et al., 1996). Briefly, total RNA was isolated by the method of Chomczynski and Sacchi (1987). Before cDNA synthesis, the RNA was treated with $1 \mathrm{U}$ DNase-1 (bovine pancreas; Sigma) for $15 \mathrm{~min}$ at room temperature in 10

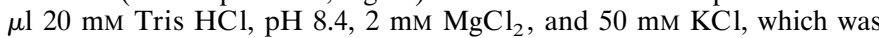
then inactivated by incubation at $65^{\circ} \mathrm{C}$ for $10 \mathrm{~min}$ with $2.5 \mathrm{~mm}$ EDTA. Single-stranded cDNA was synthesized from $1.5 \mu \mathrm{g}$ total RNA incubated in a $20 \mu \mathrm{l}$ reaction containing $50 \mathrm{ng}$ random hexamers, $2.5 \mathrm{mM} \mathrm{MgCl}_{2}, 0.5$ mM dNTPs, $10 \mathrm{~mm}$ 1,4-dithiotreitol, $50 \mathrm{~mm} \mathrm{KCl,} 20 \mathrm{~mm}$ Tris-HCl, pH 8.4, and $200 \mathrm{U}$ reverse transcriptase (Superscript Preamplification System for First Strand cDNA Synthesis, Life Technologies) for $10 \mathrm{~min}$ at $25^{\circ} \mathrm{C}$ followed by $50 \mathrm{~min}$ at $42^{\circ} \mathrm{C}$. The reaction was terminated by heating at $70^{\circ} \mathrm{C}$ for $15 \mathrm{~min}$. The sample was then incubated with $1 \mu \mathrm{l}$ of RNase $\mathrm{H}$ for $20 \mathrm{~min}$ at $37^{\circ} \mathrm{C}$. To control for the possibility of contaminating genomic DNA, RNA samples were included that were not subjected to reverse transcriptase. Gene-specific primers for selected mouse MIP-1 $\alpha$ receptors were designed as listed in Table 1. PCR was performed in a reaction mixture containing $2 \mathrm{mM} \mathrm{MgCl}_{2}, 0.5 \mu \mathrm{M}$ primers, $10 \mathrm{~mm}$ Tris-HCl, pH 8.3, $50 \mathrm{~mm} \mathrm{KCl}$, and 4 U/70 $\mu$ l Amplitaq DNA Polymerase (Perkin-Elmer, Modesto, CA). With the exception of CCR4, the PCR program was as follows: preincubation at $94^{\circ} \mathrm{C}$ for $1 \mathrm{~min}$ and then $85^{\circ} \mathrm{C}$ while enzyme was added, 27 cycles of PCR at $94^{\circ} \mathrm{C}$ for $45 \mathrm{sec}$ plus $45 \mathrm{sec}$ annealing and $1 \mathrm{~min} 72^{\circ} \mathrm{C}$ extension. The annealing temperatures used were $52^{\circ} \mathrm{C}$ for $\mathrm{CCR} 1$ and $\mathrm{MIP}-1 \alpha \mathrm{R}$-like\# $1,55^{\circ} \mathrm{C}$ for $\beta$-glucuronidase. For CCR 4 the modifications included 30 cycles of PCR at an annealing temperature of $60^{\circ} \mathrm{C}$. Six microliters of the PCR mixtures were visualized on a $1.5 \%$ agarose gel, except for the orphan receptor termed MIP- $1 \alpha \mathrm{R}$ like\#1 PCR from which $70 \mu \mathrm{l}$ was precipitated and resuspended in $6 \mu \mathrm{l}$ and then run on a $1.5 \%$ agarose gel.

Preparation of riboprobes. A fragment of mouse CCR1 including nucleotides $62-461$ of the coding region was amplified by PCR using the PE cell cDNA library (Bozic et al., 1994) as template. The $100 \mu \mathrm{l} \mathrm{PCR}$ mixture contained $5 \mu \mathrm{l}$ of the PE cDNA library, $5 \mathrm{~mm}$ dNTPs, $5 \mu \mathrm{l}$ of dimethylsulfoxide, $10 \mu \mathrm{l}$ of $10 \times$ PCR buffer, $2.5 \mathrm{U}$ of cloned PFU DNA polymerase (Stratagene, La Jolla, CA), and $0.5 \mu \mathrm{M}$ each primer. The 5 '-primer (ATCTCGAGCCACTCCATGCCAAAAGACTG) and the 3'-primer (ATGCGGCCGCTGGTGATGATGCCAAGAG) contained a $X h o I$ and a NotI restriction site, respectively. PCR was performed at $94^{\circ} \mathrm{C}$ for $1 \mathrm{~min}, 42^{\circ} \mathrm{C}$ for $1 \mathrm{~min}$, and $72^{\circ} \mathrm{C}$ for $1 \mathrm{~min}$ over 26 cycles.

The PCR product was precipitated, ligated into the pCR-Script 228 Amp SK (+) cloning vector, and transformed into Epicurian Coli XL1Blue MRF' Kan supercompetent cells using the pCR-Script 228 Amp SK $(+)$ cloning kit (Stratagene). The cloning vector contains a T3 promoter upstream from the cloning site. The transformation reaction was plated on agar plates containing ampicillin, $\mathrm{X}$-gal, and isopropylthio- $\beta$-Dgalactoside and incubated overnight. White colonies were selected and grown overnight in a liquid culture. Plasmids were purified using the Wizard Plus Minipreps DNA Purification Systems (Promega, Madison, WI). The purified plasmids were digested with XhoI and HindIII as well as with NotI and HindIII (New England Biolabs, Beverly, MA). A HindIII restriction site is present at position 319 of the nucleotide sequence of mouse CCR1. Plasmids containing the cloned mouse CCR1 fragment in an antisense orientation were used for RNA transcription. To prepare the antisense riboprobe, the plasmid was digested with Bam HI; this restriction site is located downstream from the cloning site of the vector. A digest with $S a c$ I was performed to prepare the sense 


\section{Astrocytes}

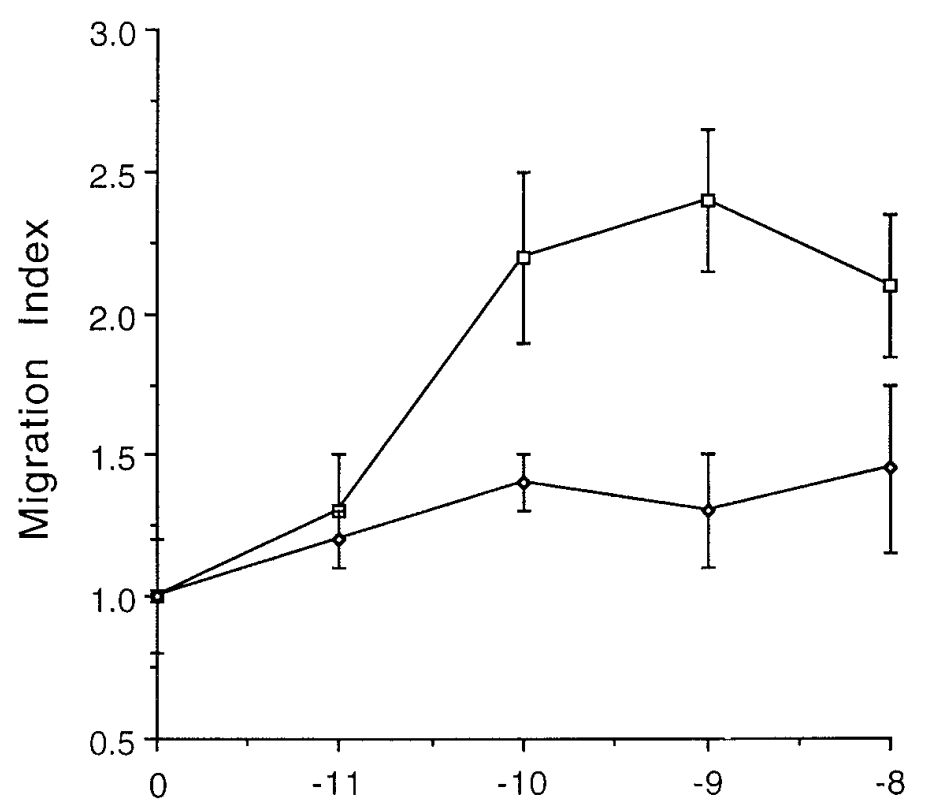

Macrophages

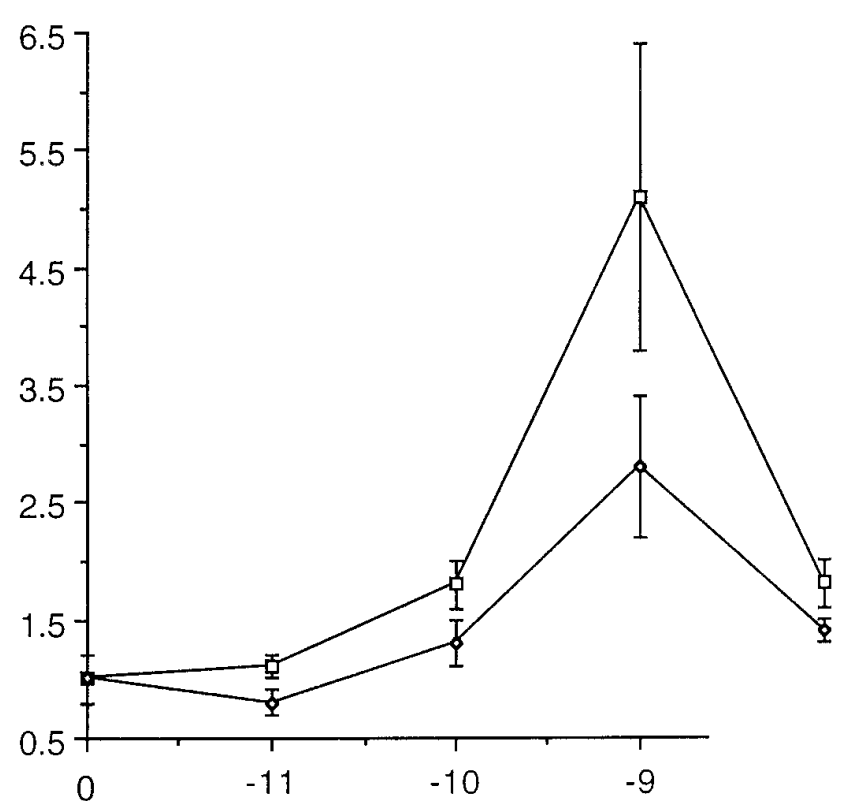

Log Chemokine Concentration (M)

Figure 1. Mouse astrocyte (left panel) or macrophage (right panel) migration across a membrane in response to various doses of the mouse $\beta$-chemokines MIP-1 $\alpha$ (square) and MIP-1 $\beta$ (diamond). The average number of migrating cells per high-powered field were divided by the background migration in the medium control for presentation as the migration index. The medium control migration index $\pm \mathrm{SD}$ was $1.0 \pm 0.2$. The data represent a pool of two or three independent experiments.

riboprobe. The $\mathrm{SacI}$ restriction site is located upstream from the cloning site.

Fractions of the linearized plasmid were visualized on a gel. After precipitation and resuspension, RNA transcription and labeling with digoxigenin (DIG)-UTP was performed using the DIG RNA Labeling Kit (Boehringer Mannheim, Indianapolis, IN). Briefly, $1 \mu \mathrm{g}$ of template was incubated with $2 \mu \mathrm{l}$ of T3 RNA polymerase for the antisense riboprobe or T7 RNA polymerase for the sense riboprobe in a final volume of $20 \mu \mathrm{l}$. Two microliters of DNase were added, and after an additional $15 \mathrm{~min}$ at $37^{\circ} \mathrm{C}$ the reactions were stopped by adding $2 \mu \mathrm{l}$ of 0.2 M EDTA. The reaction mixtures were diluted 1:2 with DEPC-treated water and stored at $-80^{\circ} \mathrm{C}$.

In situ hybridization. Astrocytes or control mesangial cells, prepared as detailed elsewhere (Hayashi et al., 1993; Luo and Dorf, 1996), were cyto-centrif uged onto baked RNase-free slides. Slides were air-dried for $15 \mathrm{~min}$ and fixed in 3\% paraformaldehyde in PBS for $1 \mathrm{hr}$. The slides were incubated in $0.1 \mathrm{M}$ triethanolamine, $\mathrm{pH} 8.0$, for $5 \mathrm{~min}$ (Sigma). The cell samples were acetylated by incubation in $0.1 \mathrm{M}$ triethanolamine, $\mathrm{pH}$ 8.0 , with $0.25 \%$ acetic anhydride (Sigma) for $15 \mathrm{~min}$ and rinsed twice in $2 \times \operatorname{SSC}(0.3 \mathrm{~m}$ sodium chloride, $0.03 \mathrm{~m}$ sodium citrate). Prehybridization was performed at room temperature for $20 \mathrm{~min}$ in a buffer with $50 \%$ formamide, $4 \times$ SSC, $0.4 \times$ Denhardt's solution, $10 \%$ dextran sulfate, 250 $\mu \mathrm{g} / \mathrm{ml}$ of yeast tRNA, and $500 \mu \mathrm{g} / \mathrm{ml}$ of salmon testes DNA. The buffer was boiled for $10 \mathrm{~min}$ and incubated on ice for $5 \mathrm{~min}$ before use. Four microliters of the riboprobe were diluted in $50 \mu \mathrm{l}$ of prehybridization buffer, boiled for $5 \mathrm{~min}$, and placed in the center of a coverslip. The coverslip was inverted onto the slide, which then was sealed with nail polish and hybridized at $52^{\circ} \mathrm{C}$ for $16-18 \mathrm{hr}$. The coverslip was then removed with a razor blade, and the slides were rinsed twice with $2 \times$ SSC over 5 min followed by a rinse in STE buffer $(500 \mathrm{~mm} \mathrm{NaCl}, 1 \mathrm{~mm}$ EDTA, $\mathrm{pH}$ 8.0, $20 \mathrm{~mm}$ Tris-HCl). An incubation was performed in STE buffer containing RNase A $(50 \mu \mathrm{g} / \mathrm{ml})$ for $45 \mathrm{~min}$ at $37^{\circ} \mathrm{C}$. After this, slides were incubated in $2 \times \mathrm{SSC} / 50 \%$ formamide for $10 \mathrm{~min}$ at $50^{\circ} \mathrm{C}$, rinsed one time in $1 \times \mathrm{SSC}$ and three times in $0.5 \times \mathrm{SSC}$ for $5 \mathrm{~min}$ each time. A final rinse over $5 \mathrm{~min}$ was performed in buffer $1(100 \mathrm{mM}$ Tris- $\mathrm{HCl}, \mathrm{pH} 7.5,150 \mathrm{~mm} \mathrm{NaCl}$ ) containing $0.2 \%$ BSA. The slides were preincubated in $2 \%$ normal rabbit serum in buffer 1 for $20 \mathrm{~min}$ before incubating with sheep anti-DIG-AP F(ab) (Boehringer Mannheim), diluted 1:500 in buffer 1 , for $60 \mathrm{~min}$. The slides were rinsed one time in buffer 1 and incubated for $10 \mathrm{~min}$ in buffer 2 (100 mM Tris-HCl, $\mathrm{pH} 7.5$, $100 \mathrm{~mm} \mathrm{NaCl}, 50 \mathrm{~mm} \mathrm{MgCl}_{2}$ ). The substrate solution consisting of 450 $\mu \mathrm{g} / \mathrm{ml}$ of 4-nitro blue tetrazolium chloride (Boehringer Mannheim), 175 $\mu \mathrm{g} / \mathrm{ml}$ of 5-bromo-4-chloro-3-indolyl phosphate toludium salt (Boehringer Mannheim), and $1.25 \mathrm{~mm}$ levamisole (Sigma) in buffer 2 was added for a $16-18 \mathrm{hr}$ incubation at $4^{\circ} \mathrm{C}$ in a light-protected room. This reaction was stopped by rinsing with buffer $3(10 \mathrm{~mm}$ Tris-HCl, $\mathrm{pH} 8.0,1 \mathrm{~mm}$ EDTA). Slides were mounted with Mount 60228 (Baxter, Deerfield, IL).

\section{RESULTS}

\section{MIP-1 $\alpha$ induces chemotactic migration of astrocytes}

The ability of the mouse $\beta$ chemokines MIP- $1 \alpha$ and MIP- $1 \beta$ to stimulate migration of cultured mouse astrocytes was examined. Various concentrations $\left(10^{-11}-10^{-8} \mathrm{M}\right)$ of the chemokines were placed in the lower well of a Boyden microchamber. Cells were separated from the lower well by a porous polycarbonate filter. Preliminary experiments indicated that astrocyte migration to MIP- $1 \alpha$ occurred after $3-4 \mathrm{hr}$ incubation at $37^{\circ} \mathrm{C}$ (data not shown). All cells that migrated to the bottom surface of the membrane stained with anti-GFAP antibody, confirming that astrocytes are responsive to MIP- $1 \alpha$ (data not shown). The total level of migration was proportional to the nonspecific background migration with control medium. Because the level of background migration varied among different batches of astrocytes (16-127 cells/well), the results from different experiments were normalized and presented as a migration index (experimental response/ control response with medium only). MIP- $1 \alpha$ consistently stimulated astrocyte migration at $10^{-10}-10^{-8} \mathrm{M}(p<0.01)$. At higher $\left(10^{-7} \mathrm{M}\right)$ concentrations, MIP- $1 \alpha$ migratory activity decreased (data not shown). Peak astrocyte migratory responses were noted 


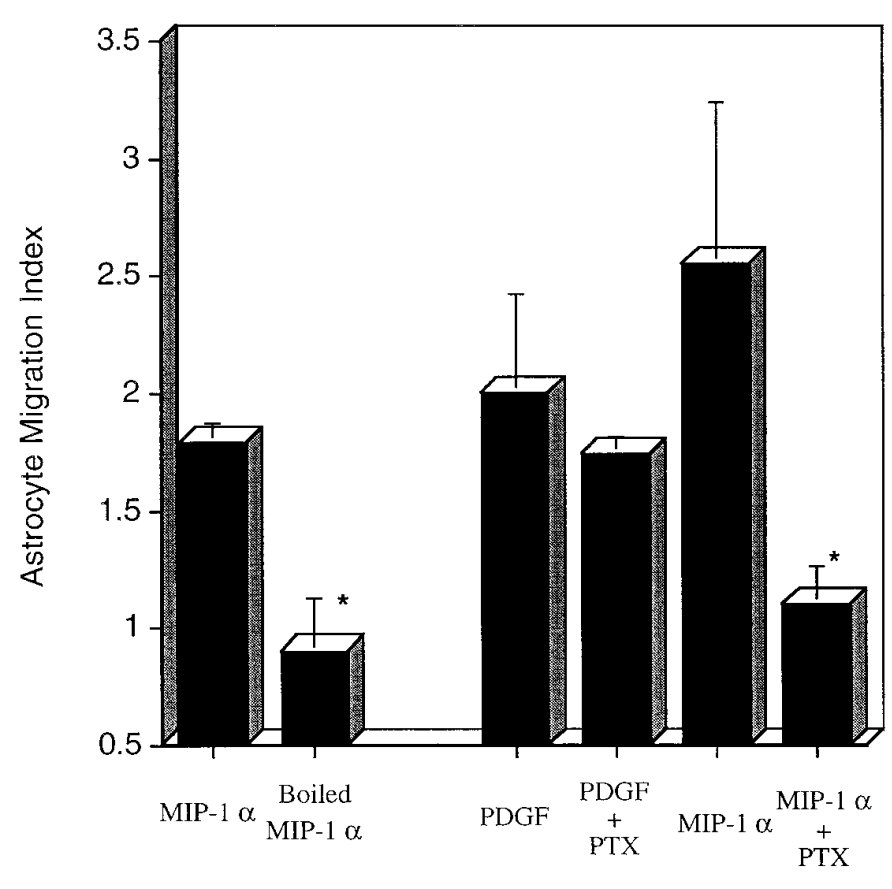

Figure 2. Inhibition of astrocyte migration by boiling MIP-1 $\alpha$ or PTx treatment of astrocytes. Astrocytes were allowed to migrate toward 10 $\mathrm{ng} / \mathrm{ml}$ native or denatured (boiled for $30 \mathrm{~min}$ ) MIP- $1 \alpha$. Astrocytes were pretreated in serum-free MEM with or without PTx $(1 \mathrm{ng} / \mathrm{ml})$ for $1 \mathrm{hr}$ at $37^{\circ} \mathrm{C}$. Stimulants of chemotaxis included PDGF-BB $(10 \mathrm{ng} / \mathrm{ml})$ and MIP-1 $\alpha(10 \mathrm{ng} / \mathrm{ml})$. The results are a composite of two representative experiments with triplicate wells. The data are expressed as migration index \pm SD. An asterisk indicates significant levels of inhibition $(p<0.05)$ versus cells treated with chemoattractant alone.

Table 2. Checkerboard analysis of astrocyte migration to MIP-1 $\alpha$

\begin{tabular}{|c|c|c|c|c|c|}
\hline \multicolumn{2}{|l|}{ Lower wells } & \multicolumn{4}{|c|}{ Upper wells MIP-1 $\alpha(\mathrm{ng} / \mathrm{ml})$} \\
\hline $\operatorname{MIP}-1 \alpha(\mathrm{ng} / \mathrm{ml})$ & 100 & 10 & 1 & 0.1 & 0 \\
\hline 100 & 150.40 & $43 \pm 11$ & $54 \pm 25 *$ & $58 \pm 14 *$ & $53 \pm 14 *$ \\
\hline 10 & $29 \pm 9$ & $\frac{11}{11}$ & $55 \pm 17 *$ & $49 \pm 9 *$ & $74 \pm 13 *$ \\
\hline 1 & $40 \pm 10$ & $34 \pm 8$ & $3.20,8$ & $44 \pm 14 *$ & $57 \pm 9 *$ \\
\hline 0.1 & $33 \pm 13$ & $26 \pm 11$ & $29 \pm 12$ & 127.910 & $38 \pm 11$ \\
\hline 0 & $27 \pm 6$ & $25 \pm 9$ & $35 \pm 14$ & $35 \pm 15$ & $(3.36=11$ - \\
\hline
\end{tabular}

The indicated final concentrations of mouse MIP-1 $\alpha$ were placed in the upper and lower wells of the Boyden chamber; $4 \times 10^{6}$ astrocytes $/ \mathrm{ml}$ were mixed with MIP- $1 \alpha$ and added to the upper chamber. Pooled results from two independent experiments, data are expressed as the mean $\pm \mathrm{SD}$. An asterisk $\left(^{*}\right)$ indicates significant migration $(p<0.05)$ compared with no chemotactic gradient (i.e., same MIP- $1 \alpha$ concentration in upper and lower chambers).

at $10^{-9} \mathrm{M}$; similar MIP- $1 \alpha$ dose-response patterns were noted with the control macrophage population (Fig. 1). In contrast, MIP-1 $\beta$ only demonstrated weak (nonsignificant, $p>0.05$ ) activity at the highest concentration tested $\left(10^{-8} \mathrm{M}\right)$ (Fig. 1). The biological activity of this preparation of MIP- $1 \beta$ was confirmed because $10^{-10}-10^{-8}$ M MIP- $1 \beta$ stimulated migration of mouse macrophages, demonstrating peak migration index of 2.8 at $10^{-9}$ M (Fig. 1). Thus, these experiments demonstrate that astrocytes can respond to subnanomolar concentrations of MIP- $1 \alpha$ but are not sensitive to MIP-1 $\beta$.

Although MIP-1 $\alpha$ consistently induces astrocyte locomotion, the magnitude of the migratory responses are generally lower than the fivefold stimulation indices noted with macrophages (Fig. 1). Therefore, we compared the levels of astrocyte migration between MIP-1 $\alpha$ and the established astrocyte attractant PDGF (Bressler et al., 1985; Heesen et al., 1996). MIP-1 $\alpha$ and PDGF were equally effective at inducing chemotaxis under these experimental conditions (Fig. 2).

To determine whether the observed migration of astrocytes was attributable to chemotaxis (directed movements along a chemical gradient) rather than random cell movement (chemokinesis), various concentrations $(1-100 \mathrm{ng} / \mathrm{ml})$ of MIP- $1 \alpha$ were placed in the upper and lower wells of the Boyden microchamber. Astrocytes only migrated toward the lower chamber when a concentration gradient existed in that direction (Table 2). These results established that MIP- $1 \alpha$ induced directed migration of astrocytes.

To evaluate the thermal stability of MIP- $1 \alpha$, the chemokine was boiled for 30 min before introduction into the Boyden chamber. As shown in Figure 2, boiling completely destroyed chemotactic activity $(p<0.01)$. These results suggest that the vast majority of chemotactic activity was not attributable to endotoxin, which is stable under these experimental conditions.

\section{MIP-1 $\alpha$ responses are sensitive to PTx}

Chemokine receptors belong to the family of seven transmembrane-spanning molecules that couple to heterotrimetric G-proteins. Most chemokine receptors for MIP-1 $\alpha$ appear to couple to G-protein $\alpha_{\mathrm{i}}$ subunits, because PTx pretreatment inhibits MIP-1 $\alpha$-induced calcium mobilization (Spiegel et al., 1992; Ben-Baruch et al., 1995). To determine whether MIP- $1 \alpha$-induced astrocyte migration is mediated by a PTx-sensitive intracellular signaling pathway, astrocytes were pretreated with PTx before analysis in the chemotaxis assay. As shown in Figure 2, MIP-1 $\alpha$ induced astrocyte migration was completely inhibited by treatment with $1 \mathrm{ng} / \mathrm{ml}$ of PTx for $1 \mathrm{hr}$ at $37^{\circ} \mathrm{C}(p<0.05)$. In contrast, $\mathrm{PTx}$ did not inhibit astrocyte migration in response to PDGF-BB, because the PDGF receptor uses a different intracellular signaling pathway (Pfeilschifter et al., 1991).

\section{Expression of chemokine receptor genes}

To determine whether mouse astrocytes express CCR1, CCR4, or the orphan MIP- $1 \alpha \mathrm{R}$-like\#1 receptor, astrocyte and control PE cell RNAs were reverse-transcribed and subjected to PCR amplification. Because most chemokine receptors lack introns, we used three approaches to minimize artifacts attributable to potential genomic contamination. First, the RNAs were treated with DNase I before RT. Second, RT-PCR reactions were also run in the absence of reverse transcriptase, and finally a parallel PCR was run using primers surrounding a $90 \mathrm{bp}$ intron of the housekeeping gene $\beta$-glucuronidase. No PCR products were detected when reverse transcriptase was omitted (Fig. 3). The $\beta$-glucuronidase PCR products found in both astrocytes and PE cells had a size of $301 \mathrm{bp}$, consistent with the predicted size of the spliced cDNA (Table 1, Fig. 3). Mouse CCR1 PCR products were detected in astrocytes (Fig. 3). Because primary astrocyte cultures may be contaminated with fibroblasts, L929 fibroblasts were also tested for expression of CCR1, but no PCR products were detectable (Fig. 3). In contrast, the CCR 4 and orphan MIP- $1 \alpha$ Rlike\#1 PCR products were not detected in astrocytes but were identified in RNA from control PE cells. The failure to detect CCR4 message in astrocytes was confirmed using four primer combinations (Fig. 3). 
Figure 3. Representative RT-PCR results using murine CCR1 (546 bp), CCR4 (1090-1180 bp), the orphan MIP- $1 \alpha-$ like\#1 receptor (411 bp), and $\beta$-glucuronidase (301 bp) primers. PCR products were run with RNA from either $A$ (astrocytes), $N A$ [astrocytes with no reverse transcriptase (RT) added], $P$ (PE cells), $N P$ (PE cells with no RT added), or $F$, L929 fibroblasts.

\section{In situ hybridization}

A cloned fragment of mouse CCR1 was DIG-labeled and in vitro RNA transcribed. The probe was visualized on a nylon membrane (GeneScreen, New England Nuclear, Boston, MA) by incubating with anti-DIG-AP F(ab) and the substrate solution to confirm successful RNA transcription (data not shown). The CCR1 antisense probe specifically hybridized to the astrocyte preparation (Fig. 4). In contrast, hybridization to a negative control population of mesangial cells did not show a signal. No signal was detected when astrocytes or mesangial cells were hybridized with the control CCR1 sense probe (Fig. 4).

\section{DISCUSSION}

MIP- $1 \alpha$ is produced by various cell types, including astrocytes and microglia, after stimulation with proinflammatory agents
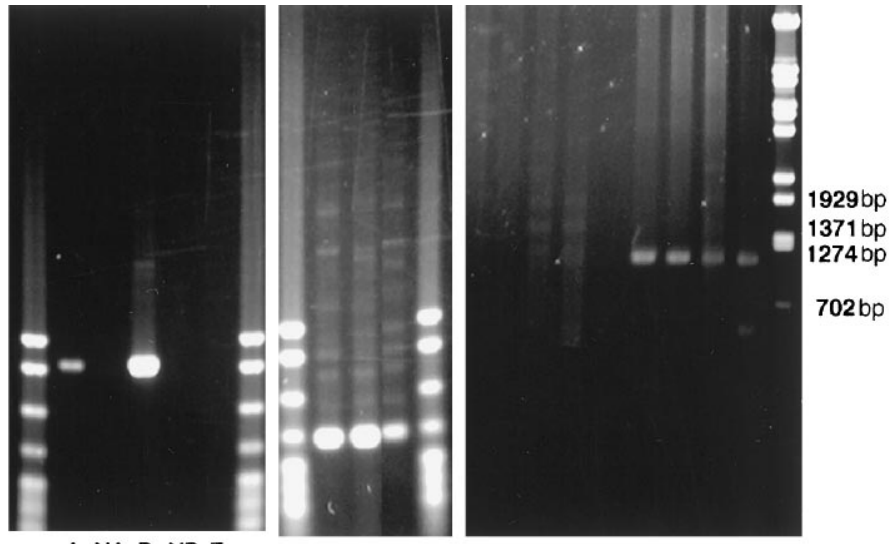

(Hayashi et al., 1995). In addition to astrocytes, MIP-1 $\alpha$ can recruit monocytes and microglia. The combined data suggest that there may be an autocrine loop in which MIP-1 $\alpha$ attracts and activates astrocytes at sites of inflammation. Murine MIP- $1 \alpha$ is an effective chemoattractant of GFAP-positive astrocytes at subnanomolar concentrations. Peak chemotactic responses were noted at $10^{-9} \mathrm{M}$ (Fig. 1). These results are consistent with the finding that RNA for the MIP- $1 \alpha$ binding receptor CCR1 was detected in astrocytes by both RT-PCR (Fig. 3) and in situ hybridization (Fig. 4).

Mouse CCR1 and CCR4 have high affinity for murine MIP-1 $\alpha$ with affinities of 1-10 × $10^{-9} \mathrm{M}$ [(Gao and Murphy, 1995; Post et al., 1995; Hoogewerf et al., 1996). Expression of RNA for CCR4 in mouse brain or astrocytes was not examined previously; however, two independent reports noted that CCR1 was not detect-
Astrocytes
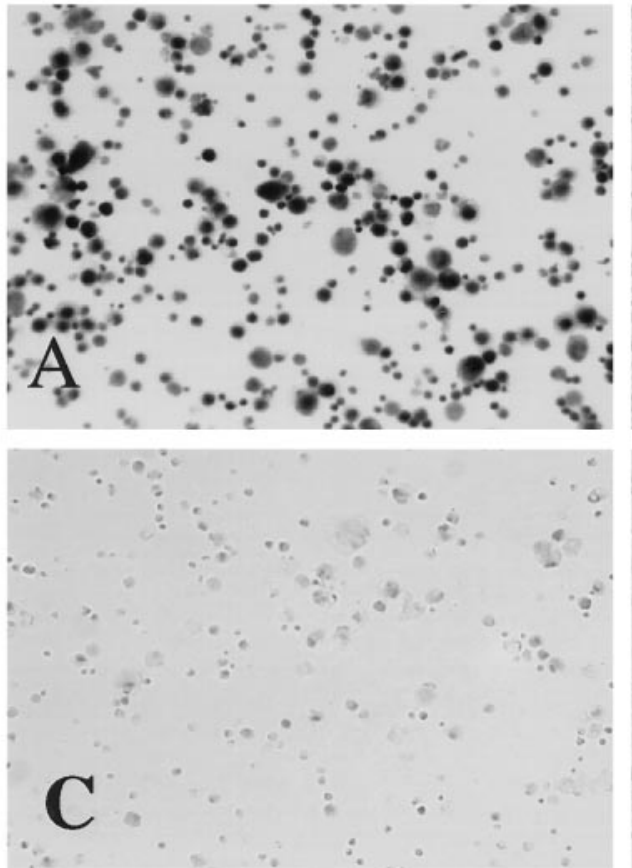

Mesangial cells
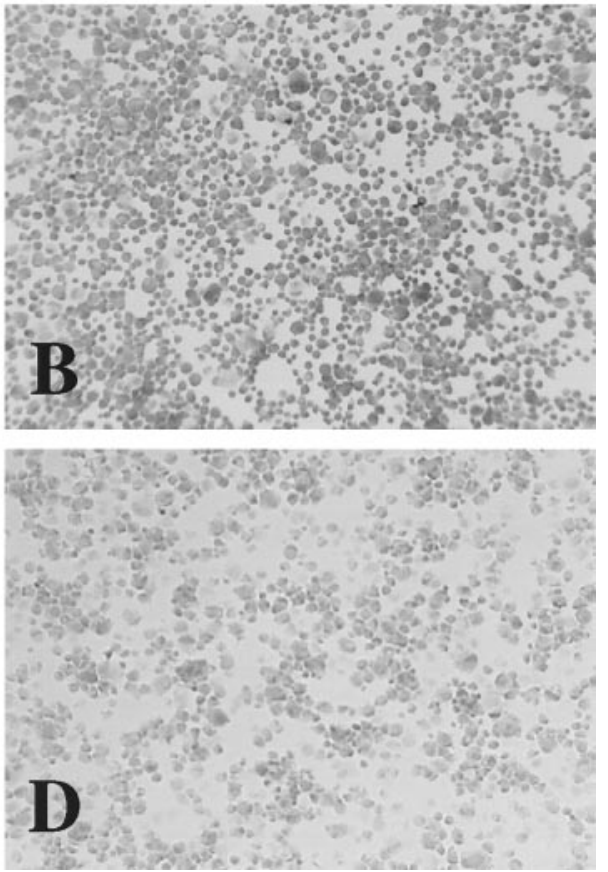

\section{CCR1 sense RNA-probe}

Figure 4. In situ hybridization of CCR1 antisense $(A, B)$ and sense $(C, D)$ riboprobes to cultured astrocytes (left panels). Hybridization of the same probes to cultured mouse mesangial cells (right panels) were included as negative controls. Cells were viewed at a magnification of $50 \times$. 
able in normal brain tissue by Northern blot (Gao and Murphy, 1995; Post et al., 1995). In the present studies, the more sensitive RT-PCR technique was used to identify CCR1 in mRNA from cultured astrocyte populations. This finding was confirmed independently by in situ hybridization.

Very few studies have monitored the expression of chemokine receptors on astrocytes. Tada et al. (1994) first screened for the expression of the type B IL-8 receptor (CXCR2) on human glioblastoma cell lines and tissue samples; they detected CXCR2 mRNA in some samples but not in cultured human astrocyte samples. Lacy et al. (1995) also reported variable expression of CXCR2 on human astrocytes. The function of chemokine receptors in cells of the CNS was not explored in either of the previous studies. The present studies combine RT-PCR with functional studies and represent the first evidence that functional chemokine receptors are expressed on astrocytes. Expression of these receptors may be important in the pathogenesis of reactive astrogliosis.

Chemokine receptors are seven transmembrane-spanning molecules that couple to G-proteins (Spiegel et al., 1992; Ben-Baruch et al., 1995). In leukocytes, chemokine-mediated biological activities such as chemotaxis, arachidonic acid release, and $\mathrm{Ca}^{2+}$ influx are partially or completely inhibited by PTx (Locati et al., 1994; Sozzani et al., 1994; Bacon et al., 1995; Bizzarri et al., 1995; Myers et al., 1995). PTx ADP-ribosylates C-terminal $\alpha_{\mathrm{i}}$ subunits of the heterotrimeric G-proteins, resulting in functional uncoupling with the seven transmembrane-spanning receptors (Spiegel et al., 1992). In the present study, MIP- $1 \alpha$-induced astrocyte migration was also sensitive to PTx treatment (Fig. 2), further supporting the functional role of chemokine receptor proteins in astrocyte chemotaxis. The combined data suggest that astrocyte chemokine receptors may use the same family of G-proteins used by leukocyte chemokine receptors.

Treatment of mice with anti-MIP- $1 \alpha$ prevents recruitment of inflammatory cells into the CNS (Karpus et al., 1995). MIP-1 $\alpha$ may contribute to inflammation within the CNS by altering the integrity of the blood-brain barrier. Astrocyte processes form the endfeet surrounding the CNS microvessels. The astrocyte interactions with capillary and venule endothelial cells appear to be responsible for formation of the characteristic tight junctions of the blood-brain barrier (Mucke and Eddleston, 1993). Breakdown of the blood-brain barrier and leakage of blood-borne substances into the CNS have been implicated in the astrogliosis observed in EAE (Eng et al., 1996). Thus chemokines such as MIP-1 $\alpha$ may facilitate entry of inflammatory cells into the CNS and contribute to the pathogenesis of autoimmune and infectious diseases.

\section{REFERENCES}

Alam R, Forsythe PA, Stafford S, Lett-Brown MA, Grant JA (1992) Macrophage inflammatory protein- $1 \alpha$ activates basophils and mast cells. J Exp Med 176:781-786.

Bacon KB, Premack BA, Gardner P, Schall T (1995) Activation of dual $\mathrm{T}$ cell signaling pathways by the chemokine RANTES. Science 269:1727-1730.

Baggiolini M, Dewald B, Moser B (1994) Interleukin-8 and related chemotactic cytokines-CXC and $\mathrm{CC}$ chemokines. Adv Immunol 55:97-179.

Ben-Baruch A, Michiel DF, Oppenheim JJ (1995) Signals and receptors involved in recruitment of inflammatory cells. J Biol Chem 270:11703-11706.

Bizzarri C, Bertini R, Bossu P, Sozzani S, Montovani A, Damme JV, Tagliabue A, Boraschi D (1995) Single-cell analysis of macrophage chemotactic protein-1-regulated cytosolic $\mathrm{Ca}^{2+}$ increase in human adherent monocytes. Blood 86:2388-2394.
Bozic CR, Gerard NP, von Uexkull-Guldenband C, Kolakowski Jr LF, Conklyn MJ, Breslow R, Showell HJ, Gerard C (1994) The murine interleukin 8 type B receptor homologue and its ligands. J Biol Chem 169:29355-29358.

Bressler JP, Grotendorst GR, Leitov C, Hjelmeland LM (1985) Chemotaxis of rat brain astrocytes to platelet derived growth factor. Brain Res 344:249-254.

Chomczynski P, Sacchi N (1987) Single-step method of RNA isolation by acid guanidinium thiocyanate-phenol-chloroform extraction. Anal Biochem 162:156-159.

Cook DN, Beck MA, Coffman TM, Kirby SL, Sheridan JF, Pragnell IB, Smithies O (1995) Requirement of MIP- $1 \alpha$ for an inflammatory response to viral infection. Science 269:1583-1585.

Devi S, Laning J, Luo Y, Dorf ME (1995) Biologic activities of the $\beta$-chemokine TCA3 on neutrophils and macrophages. J Immunol 154:5376-5383.

Eng LF, Ghirnikar RS, Lee YL (1996) Inflammation in EAE: role of chemokine/cytokine expression by resident and infiltrating cells. Neurochem Res 21:511-525.

Gao J-L, Murphy PM (1995) Cloning and differential tissue-specific expression of three mouse $\beta$ chemokine receptor-like genes, including the gene for a functional macrophage inflammatory protein- $1 \alpha$ receptor. J Biol Chem 270:17494-17501.

Glabinski AR, Tani M, Aras S, Stoler MH, Tuohy VK, Ransohoff RM (1995) Regulation and function of central nervous system chemokines. Int J Dev Neurosci 13:153-165.

Godiska R, Chantry D, Dietsch GN, Gray PW (1995) Chemokine expression in murine experimental allergic encephalomyelitis. J Neuroimmunol 58:167-176.

Hayashi M, Dorf ME, Abromson-Leeman S (1993) Granulocytemacrophage colony stimulating factor inhibits class II major histocompatibility complex expression and antigen presentation by microglia. J Neuroimmunol 48:23-32.

Hayashi M, Luo Y, Laning J, Strieter RM, Dorf ME (1995) Production and function of monocyte chemoattractant protein-1 and other $\beta$-chemokines in murine glial cells. J Neuroimmunol 60:143-150.

Heesen M, Tanabe S, Berman MA, Yoshizawa I, Luo Y, Kim RJ, Post WT, Gerard C, Dorf ME (1996) Mouse astrocytes respond to the chemokines MCP-1 and KC but RT-PCR does not detect mRNA for the KC or new MCP-1 receptor. J Neurosci Res 45:382-391.

Hoogewerf AJ, Black D, Proudfoot AEI, Wells TNC, Power CA (1996) Molecular cloning of murine CC CKR-4 and high affinity binding of chemokines to murine and human CC CKR-4. Biochem Biophys Res Commun 218:337-343.

Karpus WJ, Lukacs NW, McRae BL, Strieter RM, Kunkel SL, Miller SD (1995) An important role for the chemokine macrophage inflammatory protein- $1 \alpha$ in the pathogenesis of the T cell-mediated autoimmune disease, experimental autoimmune encephalomyelitis. J Immunol 155:5003-5010.

Kim JS, Gautam SC, Chopp M, Zaloga C, Jones ML, Ward PA, Welch KMA (1995) Expression of monocyte chemoattractant protein-1 and macrophage inflammatory protein- 1 after focal cerebral ischemia in the rat. J Neuroimmunol 56:127-134.

Kuchroo VK, Martin CA, Greer JM, Ju S-T, Sobel RA, Dorf ME (1993) Cytokines and adhesion molecules contribute to the ability of myelin proteolipid protein-specific $\mathrm{T}$ cell clones to mediate experimental allergic encephalomyelitis. J Immunol 151:4371-4382.

Lacy M, Jones J, Whittemore SR, Haviland DL, Wetsel RA, Barnum SR (1995) Expression of the receptors for the C5a anaphylatoxin, interleukin-8 and FMLP by human astrocytes and microglia. J Neuroimmunol 61:71-78.

Locati M, Zhou D, Luini W, Evangelista V, Mantovani A, Sozzani S (1994) Rapid induction of arachidonic acid release by monocyte chemotactic protein-1 and related chemokines. Role of $\mathrm{Ca}^{2+}$ influx: synergism with platelet-activating factor and significance for chemotaxis. J Biol Chem 269:4746-4753.

Luo Y, Dorf ME (1996) $\beta$-Chemokine TCA3 binds to mesangial cells and induces adhesion, chemotaxis, and proliferation. J Immunol 156:742-748.

McColl SR, Hachicha M, Levasseur S, Neote K, Schall TJ (1993) Uncoupling of early signal transduction events from effector function in human peripheral blood neutrophils in response to recombinant macrophage inflammatory protein- $1 \alpha$ and $-1 \beta$. J Immunol 150:4550-4560. Meyer A, Coyle AJ, Proudfoot AEI, Wells TNC, Power CA (1996) 
Cloning and characterization of a novel murine macrophage inflammatory protein- $1 \alpha$ receptor. J Biol Chem 271:14445-14451.

Mucke L, Eddleston M (1993) Astrocytes in infectious and immunemediated diseases of the central nervous system. FASEB J 7:1226-1232.

Myers SJ, Wong LM, Charo IF (1995) Signal transduction and ligand specificity of the human monocyte chemoattractant protein-1 receptor in transfected embryonic kidney cells. J Biol Chem 270:5786-5792.

Pfeilschifter J, Hosang M (1991) Effects of homo- and heterodimeric isoforms of PDGF on signaling events in rat renal mesangial cells. Cell Signal 3:413-424.

Post TW, Bozic CR, Rothenberg ME, Luster AD, Gerard N, Gerard C (1995) Molecular characterization of two murine eosinophil $\beta$ chemokine receptors. J Immunol 155:5299-5305.

Rot A, Krieger M, Brunner T, Bischoff SC, Schall TJ, Dahinden CA (1992) RANTES and human macrophage inflammatory protein (MIP)-1 $\alpha$ induce the migration and activation of normal human eosinophil granulocytes. J Exp Med 176:1489-1495.

Schmidtmayerova H, Nottet HSM, Nuovo G, Raabe T, Flanagan CR, Duborovsky L, Gendelman HE, Cerami A, Bukrinsky M, Sherry B (1996) Human immunodeficiency virus type 1 infection alters chemokine $\beta$ peptide expression in human monocytes: implications for recruitment of leukocytes into brain and lymph nodes. Proc Natl Acad Sci USA 93:700-704.
Smith ME, Somera FP, Eng L (1983) Immunocytochemical staining for glial fibrillary acidic protein and the metabolism of cytoskeletal proteins in experimental allergic encephalomyelitis. Brain Res 264:241-253.

Sozzani S, Zhou D, Locati M, Rieppi M, Proost P, Magazin M, Vita N, Damme JV, Mantovani A (1994) Receptors and transduction pathways for monocyte chemotactic protein-2 and monocyte chemotactic protein-3. Similarities and differences with MCP-1. J Immunol 152:3615-3622.

Spiegel AM, Schenker A, Weinstein LS (1992) Receptor-effector coupling by $G$ proteins: implications for normal and abnormal signal transduction. Endocr Rev 13:536-565.

Tada M, Diserens AC, Desbaillets I, de Tribolet N (1994) Analysis of cytokine receptor messenger RNA expression in human glioblastoma cells and normal astrocytes by reverse-transcription polymerase chain reaction. J Neurosurg 80:1063-1073.

Taub DD, Conlon K, Lloyd AR, Oppenheim JJ, Kelvin DJ (1993) Preferential migration of activated CD4 + and $\mathrm{CD} 8+\mathrm{T}$ cells in response to MIP- $1 \alpha$ and MIP-1 $\beta$. Science 260:355-358.

Wolpe SD, Davatelis G, Sherry B, Beutler B, Hesse DG, Nguyen HT, Moldawer LL, Nathan CF, Lowry SF, Cerami A (1988) Macrophages secrete a novel heparin-binding protein with inflammatory and neutrophil chemokinetic properties. J Exp Med 167:570-581. 